\title{
Generic Multiplicity in Alasdair Gray's Lanark: A Life in 4 Books
}

\author{
Luis de Juan Hatchard \\ University of Zaragoza
}

\begin{abstract}
This paper begins by acknowledging the ontological multiplicity which characterises the fictional world(s) of Lanark: A Life in 4 Books, and suggests the need to complement this reading by looking into its generic multiplicity. In doing so, my analysis initially focuses on the opposition between the realistic and fantastic narratives, and the revitalising effect that such a relationship brings about; then it looks into how the novel blurs the frontiers between dystopian and utopian writing as well as between fantasy and science fiction, and contends that such a mélange is an effective way of providing a panoramic view of contemporary Western society; finally, my analysis pays special attention to the Epilogue, which adds a metafictional dimension to the novel, and comments on the different interpretations that may be given to this display of narrative experimentation.
\end{abstract}

There is general agreement that one of the distinctive features of postmodernist literature is its pervasive ontological multiplicity. Brian McHale has made of the opposition between the epistemological dominant and the ontological dominant the basic feature which enables us to understand the transition from modernism to postmodernism. It is his contention that postmodemist narratives should be approached by raising the following questions: What is a world? What kinds of world are there, how are they constituted, and how do they differ? What happens when different kinds of world come into confrontation, or when boundaries between worlds are violated? What is the mode of existence of a text, and what is the mode of existence of the world (or worlds) it projects? (1987:10). Although some attention has been paid to the different worlds which constitute the ontological space of Lanark (Lyall 
1993; Costa 1994), not that much has been said about the generic multiplicity of the text. It is precisely the aim of this article to show how the multiplicity of ontological areas is backed by a similar generic multiplicity. The present article does not set out to enter the ever-present debate on genre theory. It follows the traditional threefold typology which distinguishes between poetry, drama and narrative, and, in line with Genette, refers to them as arch-genres (1977). Within the arch-genre of narrative, Lanark's status as a novel needs little justification, and the analysis focuses on the affinities that Gray's first novel has with a number of sub-genres, or types of novel. Todorov has stated that genres work as horizons of expectation for the readers and as writing models for the authors (1987), and that accordingly authors write with the existing generic system in mind and readers are fully conditioned (whether consciously or unconsciously) by the generic system. The present analysis will enquire into these two elements, and will try to explain the reasons for this generic multiplicity and how it affects the reader.

McHale makes use of Foucault's concept of heterotopia to refer to those worlds which are defined by a feeling of discontinuity and inconsistency, by a degree of incompatibility, and which seem to have been ordered according to alternative systems of logic. He suggests the term "zone" for these areas of experience, and refers to "Alasdair Gray's zone (in Lanark, 1981), a space of paradox modeled on the Wonderland and Looking-glass worlds of the Alice books, [which] has been displaced to the ambiguous no man's land between cities" (1987:44). Although McHale only defines as a zone the Intercalendrical area between the Institute and Unthank, I believe that the whole fictional universe of Lanark may be defined in similar terms: it is a universe constituted by the worlds of Glasgow and that of Unthank, and the relationship between them, both in terms of space and time, is open to a number of interpretations. Besides, the world of Unthank is characterised by its own ontological diversity, since it consists of a number of other sub-worlds such as the Institute, Greater Unthank, and Provan, and presents two such ambiguous and complex areas as the Intercalendrical Zone (acting asa kind of link between the Institute and Unthank) and the Epilogue room (somewhere in Provan). What is revealing for our analysis is to realise how this ontological instability comes hand in hand with a similar generic instability. Playing with the parallelism between the word and the world, Colin Manlove has referred to the fact that

Lanark is not a single literary mode, but a mélange, a fictional city, of allegory, novel and fantasy: we are not allowed to settle to any one world or genre, but find that what starts as apparent realism (with Lanark in a café in a city) slips away as we see Lanark growing 'dragonhide', and then switches back as we move in the next book to the very 'realistic' history of Thaw, living in Glasgow; and so on (1994:198).

Manlove points in the right direction, but only accounts for the transition from Book Three, with which the novel begins, to Book One, which comes next, already ignoring the presence of a disturbing prologue -a brief autobiographical account which also moves from realism to fantasy- in between. We should add that the realistic narrative of Book One is followed by a short return to the fantasy world by means of the brief interlude which separates Book 
One from Book Two. Book Two continues with the realistic narrative of Book One, although its final chapters seem to have been written in a surrealistic mode, favouring confusion and ambiguity, and working perhaps as transitional chapters towards the coming section. Finally, the narrative moves back to the fantastic mode in Book Four, which is maintained until the end of the novel, although violently interrupted by the disturbing Epilogue, neither realism nor fantasy, but a most explicit metafictional piece of writing. ${ }^{1}$ One of the immediate implications of this disorder is that no single narrative is allowed to move straight, thus preventing the reader from attaining any sense of linear development. Neither narrative is given priority, and although we begin with the fantastic mode of Books Three and Four, the fact is that this narrative is cut into two; the possible interpretation of its being the product of Thaw's mind also problematises its preferential position. Likewise, the realistic narrative of Books One and Two is also split into two, defeating any sense of continuity, and its possible priority position is undermined by its being the product of the Oracle, a character belonging to the fantastic narrative. It seems that it is no longer possible to separate the fantastic from the realistic mode of narration: first because they are constantly intermingling, and next because each narrative may be interpreted as being the product of the other. This is probably one of the reasons why Manlove, perhaps pushing the issue too far, has suggested that the novel may be read in both directions, that the story may go backwards as readily as forwards, moving from Thaw to Lanark as well as from Lanark to Thaw. If the dislocated and fragmented narrative poses questions about how to interpret the content itself -"the dislocated narrative asks us which is 'first', Thaw's world or Lanark's; and which is more fantastic, the world of Glasgow or of Unthank [...] our notions of what is real, what fantastic, what first, what last, are thus displaced, at the same time as being confused" (Manlove 1994:207)- it also raises similar questions as to the tradition in which the novel is to be inserted, as well as about the difficulties of clearly defining the genre and narrative mode which are used.

Manlove's initial opposition between the realistic mode and the fantastic mode is better understood if we incorporate an analysis of the generic instability. Thus it has been widely acknowledged that the narrative of Books One and Two may well be defined within the parameters of the Glasgow novel, i.e. a realistic text which focuses on life in a postindustrial city characterised by material deprivation and spiritual hopelessness, and where the poverty of the slums adequately expresses the experience of despair, whether social, economic or artistic. In the first two Books of Lanark we witness Duncan Thaw's struggle to find a place in Glasgow, his failure when trying to define his own identity, and the continuous feeling of defeat together with the presentation of Glasgow as a city which is oppressive, claustrophobic, bleak, limiting, a place infused with an atmosphere of violence and aggression, of failed living and disenchantment. ${ }^{3}$ The best examples of this Scottish literary tradition are Edwin Muir's Poor Tom (1932), George Blake's The Shipbuilders (1935), and Edward Gaitens' Dance of the Apprentices (1948) and it reaches its zenith with the publication of Archie Hind's The Dear Green Place (1966). Should Books One and Two have been published alone, it would have been yet another example, stale and sterile, of a literary tradition in need of renewal. However, it is given fresh life by the presence of Books 
Three and Four, a narrative written in the fantastic mode which privileges an atmosphere of uncertainty and ambiguity, and inevitably puts the reader under a certain strain. Indeed, it is Bell's contention that by making use of this fantastic mode Gray revitalises and gives a new impetus to what would otherwise be a traditional Glasgow novel, thus creating his own personal brand of magic realism (1996: 233). This revitalising process is important in itself, but what I consider to be equally significant is that it is largely effected by the use of fantasy, which may be considered another of the main traditions of Scottish literature. If Witschi and Gifford, together with Moira Burgess, have underlined Lanark's position asa milestone in the Glasgow novel tradition, Manlove has done something similar by underscoring the important place which Gray's first novel occupies in Scottish fantasy literature. ${ }^{4}$ Although he does not make it clear whether this Scottish tradition was in need of change, his brief analysis of Lanark is sufficiently explicit as to the innovations involved in Gray's work.

Apart from this confusing relationship tetween reality and fantasy, a high degree of ambiguity seems to lie in the special nature of this fantastic world. If fantasies are traditionally conceived as ways of escape, of evasion, this is certainly not the case in Lanark. It is precisely a way out that Duncan Thaw is looking for at the end of Book Two, whether it is by means of his neurosis or by means of his suicide. ${ }^{5}$ However, both interpretations are represented by an inward movement, either by a retreat into an unstable and neurotic mind, or by a self-destroying walk into the sea; in neither case is a liberating space reached. Lanark arrives in Unthank, a world of darkness and oppression; it is a place represented by a continual narrowing and confinement, in which there is no possibility of expansion. In what could very well be understood as a metaphor for the intellectual and spiritual void which characterises this alternative world, movement is always centripetal: Lanark enters the mouth in the Necropolis and falls into the Institute; there he discovers an immense pit; he leaves the Institute and through the Intercalendrical Zone reaches Unthank, which now lies in complete decay; after a self-consuming trip and an spiral landing he descends into Provan, where he discovers vanity and fails in his political mission; and finally Lord Monboddo offers him the possibility of abandoning Provan through a tunnel which leads him back to Unthank, by now almost turned into an apocalyptic place, where he will acknowledge his failure as a husband and father and sit to await death. The fantastic mode may be partly explained by the satirical aim which becomes an essential element in Books Three and Four. Indeed, there is general agreement that satire demands at least a token of fantasy, some content that the reader recognises as grotesque (Frye 1957), and which is used to criticise the wrongs of society and seek some kind of amelioration. In his analysis of modem satire, Peter Petro (1982) refers to teaching as the chief function of satire; more revealing is his remark concerning the fascinating revival of satirical writings in the twentieth century, in which if "progress is by no means the only target of importance for the modem satirist ... it is hard to dispute its importance; in one form or another, explicitly or implicitly, "progress' turns up among targets attacked more than any other" (1982:4). This common attack on progress is obviously reflected by the recurrent interest in the working of political systems, shown especially through the medium of anti-utopia. 
It is my belief that Gray's first novel falls easily into the category of the antiutopian novel. It is doubtful whether this can be questioned, especially if we consider one of the character's explanatory remarks as to what the Institute represents. In what may be considered a somewhat clumsy move in aesthetic terms, Gray has one his characters explain that the foundation and the creature are the same thing, and that both the council and the Institute are financed by it, which is one way of stating and denouncing the subordination of political bodies to multinational firms, the subjugation of politics to economics. However, well before readers come across this explanation, they have had to deal with a certain degree of instability, as they have been forced to experience in the reading process itself the proximity between utopian and dystopian worlds, and therefore, between utopias and dystopias as narrative sub-genres, thus vindicating Trousson's suggestion that we need to see both utopian and dystopian novels as two sides of the same coin, the difference lying in the value assigned to each social construction. Indeed, the picture the reader initially builds of Unthank (in Book Three) is rather negative, in Ian Spring's words "a clearly perverse dystopian version of the city of Glasgow" (1990:92): it is a grim, decaying city, characterised by the absence of light and of instruments with which to measure time, by the difficulties to differentiate one day from another, and by a generalised precariousness and instability; it is a place where no work is to be found, and people have to spend the whole day idling, from pubs to parties and vice-versa, and then back to the "Social Security Welfare Division" to get some more money; a place where people seem to disappear mysteriously, and the lack of a past and an identity have become commonplace features; a place where we read about a "big show" (p. 29) which the reader interprets as a possible Third World War; and where the reference to the "good old vertebrate Divine Image" (p. 31 ) inevitably brings to mind Nineteen Eighty-Four's Big Brother.

Living in this decaying world of Unthank, where happiness and humanity seem to have vanished, Lanark, in search of a mysterious light he sees in the distance, finds a mouth on the ground and enters it, thus reaching the Institute. This brief but intense trip seems to constitute the journey which defines the Utopian "basic narrative pattern -a visitor from another place or time encounters a superior civilization" (Kumar 1991: 26). ${ }^{6}$ Indeed, this is the reader's initial impression when s/he realises that in this new place in which Lanark has just arrived there is a time pattern, there is plenty of work, and what is more important, Lanark seems to have been cured of his disease, since no dragon hide is to be found covering his arm any more. The initial feeling is positive, and Lanark-together with the reader- believes he has arrived in a utopian space. However, despite initial and misleading appearances, this is not the case. Lanark is told that he has reached the Institute, where diseases are cured (or so it seems, since their symptoms are made to disappear, although by now the reader has come to realise that diseases may be understood as a sign of humanity), time has been restored (the decimal clock, with a totalitarian and marginalising effect, is being used), there is no unemployment (although work becomes a means of control, of fixing people's identities), there is no lack of food or drink (although this fact disguises a subtle cannibalism). In line with this disquieting atmosphere, the absolutism and totalitarianism commonly associated with utopian/dystopian systems may be realised by the 
implicit restriction of freedom which Lanark undergoes, and which has been disguised as a necessary element for the proper functioning of the Institute's machinery. Thus readers soon learn that this is a place where "nobody was moving against the wind" (p. 62), and "nobody goes against the current" (p. 63), statements which suggest the repressive nature of this social system. What initially appears to be a series of advantages which Lanark gains by arriving in the Institute gradually acquires a different meaning. This move may be said to embody the transition from a utopian to a dystopian world, thus making true Mihailescu's contention that "[d]ystopia appears not only as a critique of 'cynical reason' but also a satire on eutopia [sic]" (1991:215): readers have been witnesses to the construction of a utopian world, only to realise that such a theoretical perfection and stability has been reached at the expense of freedom and individuality. Inevitably, the awareness of the dystopian nature of the Institute affects our opinion of Unthank, now seen in a new light. The relationship between Unthank and the Institute is probably better understood by what has become a typically postmodernist metaphor, the opposition between centre and margins.

Within this fantastic/satirical narrative, a similar ambiguity may be noticed between three sub-genres, those of science fiction, fantasy and science fantasy. In his Worlds Apart: Narratology of Science Fiction, Carl D. Malmgren defines the sub-genre of science fiction by its need to base its factors of estrangement in scientific possibility and to provide for them a convincing scientific motivation or rationale (1991:6). Lanark's arrival in the Institute, after a disturbing stay in Unthank, apparently implies the reader's entrance into a world of science fiction. The scientific rationale, that of the new physics, is pointed out by Lanark himself when reflecting on the fact that "the usual laws governing the motion of bodies seemed not to apply" (p. 76), which brings to mind Nadeau's statement that "if there is anything that the new physics will inevitably violate it is common-sense expectations" (1981: 17-8). Certainly, the Institute appears as a highly technological topos: a place ruled according to a decimal time scale, a twenty-five-hour day and a sophisticated machinery which only allows movement in one direction, but what is most shocking is the Institute's capacity to transform sick patients into energy, in what seems a literal application of one of Einstein's most famous equations, $\mathrm{E}=\mathrm{MC} 2$. While Lanark is at the Institute, the novel comes close to science fiction, and focuses on the confrontation between the self and society as well as between the self and technology, and thus draws the reader's attention to the restriction of freedom to which the individual is subjected in contemporary society. Not surprisingly, Lanark decides to leave.

The walk through the Intercalendrical Zone, a disturbing space which lies outside the Institute, implies access to a kind of fantastic nature: it is an area which seems to be well beyond the Institute's control, where scientific and technological development appear to have little influence. Before their departure, both characters are cautioned about the lack of rational explanations for a number of events, and are warned that "a month is as meaningless there as a minute or a century" and that "the journey will simply be easy or strenuous or a combination of both" (p. 374). Symptomatically, this trip takes the characters through an area covered with a thick mist and along roads which go up and down simultaneously; it is an area where events undermine our traditional system of logic, 
especially by proving the inefficiency of the paradigmatic principle of cause and effect; and, most disturbingly, time may no longer be conceived in absolute terms as a linear sequence of past, present and future. In this disturbing walk Rima and Lanark come across a tall blonde girl squatting on the road and crying, which is a scene of Rima seeing herself in the past (p. 378) and a little later they listen to a dialogue that belongs to the future (p. 381). Inevitably, these disturbingly new conditions of life bring into question the very nature of this area or zone, which becomes one of the most effective ways of exploring ontological propositions: at this point, characters and readers alike are forced to ask questions about what type of 'world' this is, how it is constituted and so on, that is, to revise traditional assumptions for understanding reality.

Not surprisingly, back in Unthank, Greater Unthank and Provan the reader seems to encounter what may be defined as hybrid worlds. On the one hand, the lack of freedom caused by the dependence upon the Institute: answering Lanark's complaint that what he is given to eat is Institute food, one of the characters acknowledges that "the Quantum group delivers nothing else to us nowadays" (p. 407). On the other hand, the ontological instability that results from the proximity of the Intercalendrical Zone, whose disturbing effects are felt outside its limits. This instability is underlined by another of the characters, when stating that "until the council sends us the decimal clocks it's been promising for so long Unthank is virtually part of the Intercalendrical Zone" (p. 437). Outside the Institute, and once the Intercalendrical Zone has been left behind, the novel seems to move within the parameters of a different sub-genre, science fantasy, a hybrid form which combines features of science fiction and of fantasy: like science fiction it grounds its discourse in scientific method and scientific necessity, but like fantasy it contains some contraventions of natural laws or empirical facts (Malmgren 1991:20). Accordingly, this hybrid world combines scientific rationale plus pure fantasy: Lanark's trip to Provan is a perfect example of this mixture: he travels to Provan in a rather sophisticated aircraft -halfmachine, half-bird, but completely hollow inside- which has been designed by a certain Mrs. Schtzngrm to draw vital energy from the passenger, even from his future, if need be. Thus the world of Unthank, Greater Unthank and Provan is better understood after realising the nature of both the Institute and the Intercalendrical Zone: it is a world in decay which makes the reader wonder about the different pressures to which the human being is subjected in the contemporary postindustrial Western world, and pays special attention to the confrontation between the individual and a society run on economic and technological principles as well as to a number of ontological questions concerning the nature of the world we inhabit.

The realist section deals with the struggle of the individual to find a place in a decaying, oppressive and stultifying Glasgow. The fantasy section opens its range of action since, although there is a clear identification between Unthank and Glasgow, it is also possible to interpret the town of Unthank as a representation of any post-industrial town in the Western world. If Books One and Two provide a critique of the social dimension, Books Three and Four bring into focus aspects such as macro-economic structures and politics. The blending of the two narratives serves to underline the polymorphous nature of society as well as the difficulties involved when trying to represent and analyse it accurately. The novel looks into 
politics from a double perspective, from the personal as well as from the structural, and the mixing of narratives underlines the fact that the character's life is shaped by socially produced normative values as well as by politically determined decisions (Donaldson and Lee, 1995:155). This is most noticeable in Books Three and Four, where a grim portrait of contemporary capitalist society is carried out through a satire of its economic and political structures, and especially of the strong connections between both; it is precisely thanks to the fantastic element and its potential to defamiliarise reality that this social criticism becomes most powerful and efficient.

The entrance into the Epilogue, conveniently described as a room "with no architectural similarity to the building he had left" (p. 480), deserves a separate analysis. The generic instability or plurality referred to above may have been dealt with in an unconscious way by the reader; but at this point, the reader's active involvement -which may be considered as one of the main aims of the postmodernist agenda- is emphasised in a number of ways. In terms of content, Lanark's entrance into the Epilogue room must be understood as yet another turn of the screw in this exploration of his ontological nature: after the complex transition from the world of Glasgow to that of Unthank, and after the disturbing transition through a variety of spaces -from Unthank to the Institute, next through the Intercalendrical Zone and back to Unthank and then to Provan-Lanark is led to this room inhabited by Nastler. This encounter becomes one of the most disturbing sections of the novel, since we find both fictional author and character on the same ontological level, thus questioning such a fundamental distinction as that between fiction and reality. At this point, while Lanark wonders about his own existence, the reader cannot but wonder about the ontology of the novel itself. The issue has been raised above when referring to the Table of Contents and realising the presence of two different orders -the order of books and the order of chaptersas well as the presence of Prologue, Interlude and Epilogue, placed as if at random. The subject is again brought to the fore in the Epilogue, where both fictional author and character engage in a discussion about the genesis of the novel itself, refer to its structure and development, mention possible influences and literary tradition itself and argue about possible endings, thus turning Gray's novel into an unambiguously metafictional piece of writing, both drawing attention to its status as an artefact (Waugh 1984) and including a commentary on its own narrative and/or linguistic identity (Hutcheon 1985). In line with this thought-provoking dialogue, this self-referential chapter turns out to be a combination of four different narratives: the main narrative seems to be both complemented and undermined by the presence of an Index of Plagiarisms, a series of thirteen footnotes, and a number of independent lines functioning as introductory comments to each of the different pages. At this point a number of metafictional questions are again inevitable: what is a novel? or rather, what type of novel is this? what elements constitute a novel? what happens when different types of texts come into confrontation, or when boundaries between texts are violated?

The visual impact is important in itself. This experimental chapter may well be defined as a narrative zone, a kind of collage, a composition of juxtaposed narratives, a space which seems to privilege a degree of discontinuity and inconsistency, and which draws immediate 
attention to its own compositional nature: the vertical relationship -between text and worldwhich characterises traditional narratives is short-circuited and the emphasis is placed upon a number of horizontal relationships which inevitably defamiliarise the reading process. Through a conspicuous typographical variety and layout experimentation attention is now drawn to the physical and material dimension of the novel, that is, to the book as object. Once the reading begins, it is further problematised through a number of cross-references which again undermine the possibility of a smooth and linear reading: the headers continually refer to the main narrative; the main text is frequently interrupted by the footnotes; footnotes five and six work as links with the index; and the index itself occasionally suggests looking at footnotes six and twelve. If the conventional formats used in the writing of the novel usually foreground the horizontal axis as the only organising principle, the Epilogue forces our attention to other axes which are traditionally camouflaged and neutralised. In doing so, this chapter displays the different spaces which constitute a page and uncovers new arrangements and new possibilities for the text.

When looking into the nature of these supplementary narratives the issue is further problematised. The headers, brief ironic statements which act as introductions to or advance notices of the content of the different pages, are probably the least problematic: although not common in fiction, they may well be related to the titles which often introduce the different chapters of a novel. Evidently, their recurrent presence becomes somewhat disturbing; they draw attention to the activity of reading itself and force upon the reader some kind of choice and responsibility. The series of thirteen footnotes, despite Nastler's claim that his fiction "contains critical notes which will save research scholars years of toil" (p. 483), is probably much more ironic: in a brilliant and baffling piece of self-criticism in footnote six, Mr Sidney Workman, the fictional author of these annotations, states that "a parade of irrelevant erudition through grotesquely inflated footnotes" (p. 490) has been thieved from T.S. Eliot, Nabokov and Flann O'Brien. They bring to mind Borges's rather than T.S. Eliot's use of a similar strategy: the role of this particular critic is parodied in a number of ways -from the not very illuminating information provided in footnotes one, seven and eight to the irrelevant erudition contained in footnotes nine, ten, eleven and twelve- but these footnotes are probably better understood as a means of questioning the traditional distinction between fiction and such critical discourses as the treatise and the essay, thus undermining the world of meditation and analysis, of fact and data, perhaps implying that reasoning and data are themselves wildly fictitious. The Index of Plagiarisms, which has been classified according to a three-fold typology -block plagiarism, imbedded plagiarism, and diffuse plagiarism (p. 485)- seems to have been devised as a direct attack on academicism, a fact that Gray himself has acknowledged (in Figgis and McAllister 1988:21). This is certainly the reader's first impression, which seems to be endorsed by a number of entries devised as confusing strategies: certainly troubling are some of the entries in which Gray provides the critic (and patient reader) with some indications to be followed but not to be found (such as those which refer to Silvia Plath) and others which do exist (Mephistopheles' speech in Goethe's Faust) but seem to be of little use. Others are more problematic, and the entry on Kafka serves as a useful example: "Chap. 39, last paragraph. 
The silhouette in the window is from the last paragraph of The Trial." (p. 491). The explanation of the origin of this silhouette is hardly credible, but the reference to Kafka should not be dismissed as a piece of irrelevant information: the average reader has felt Kafka's presence throughout Books Three and Four and this is clearly a key reference for an understanding of Gray's work. Despite occasional temptations, neither the footnotes nor the index should be understood as simply a big joke and consequently dismissed as a heap of balderdash. Suffice it to acknowledge Gray's own statement that some of these entries were written with a view to paying a personal homage to some of his best friends (in Figgis and McAllister 1988:21); similarly, through the transformation of footnote thirteen into an acknowledgements section Gray (in the voice of Sidney Workman?) expresses his most sincere gratitude to Mrs. Florence Allan, who typed the book, to professor Andrew Sykes and writer James Kelman, and to thousands "whose names have not been mentioned" ( $p$. 499).

But apart from the disturbing and ambiguous presence of Index and footnotes, the Epilogue also draws the reader's attention as an explicit display of a number of strategies which underline the novel's postmodernist nature. The main narrative features a metaleptic encounter between author and character, which must be understood as a strategy for reflecting on the fictionality of the characters. This is a common aim in the plays of Samuel Beckett, Jean Genet, Tom Stoppard and Peter Handke as well as in the narrative fictions of Vladimir Nabokov, Muriel Spark, Donald Barthelme or Raymond Federman, and Nastler himself ironically acknowledges its lack of originality by admitting that it is present in Vonnegut's Breakfast of Champions. Similarly, this encounter offers a disturbing moment when Nastler hands Lanark a manuscript and we read "Much of it seemed to be a dialogue but Lanark's eye was caught by a sentence in italics which said: Much of it seemed to be a dialogue but Lanark's eye was caught by a sentence in italics which said" (p. 481), a repetition which threatens to create a structure of infinite regress, common in some narratives of Borges, John Barth, William Burroughs or Raymond Federman. In the supplementary narratives the presence of other typically postmodernist strategies is even more explicit: two such entries as those of Burns (Robert) -"Robert Burns' humane and lyrical rationalism has had no impact upon the formation of this book, a fact more sinister than any exposed by mere attribution of sources" (p. 486)- and Emerson (Ralph Waldo) "Ralph Waldo Emerson has not been plagiarized" (p. 488) provide the reader with a kind of information which cancels the very function of these entries: they are placed under erasure (McHale 1987:100). Not surprisingly, another typically postmodernist question, that of the (non-)ending, also becomes the object of attention: first through the use of circular narratives -the entry of Black (Angus) refers to Macneacail (Aonghas), which refers to Nicolson (Angus), which takes us back to Black (Angus)- thus offering the possibility of an endless process of reading. Next, through the presence of an alternative ending conveyed through a number of entries which refer to non-existent chapters $45,46,47,48,49$, and 50; this alternative ending seems to have been conceived in positive/utopian terms, although such a possibility is immediately questioned in the extremely ironic, last-but-one header, which reads "Index Ends in Hyper-Utopian Euphoria" (p. 498). Among this display of 
postmodernist strategies, probably one of the most outstanding is the suggestion of looking into the index as a source of intertextual references, which inevitably serves to underline the text's existence as a space where a number of genres and sub-genres come together and engage in a dialectical relationship. Not surprisingly, the index includes romances such as Sir Gawain and the Green Knight, the poetry of William Blake, the short stories of Jorge Luis Borges or Edgar Allan Poe, Georges Douglas Brown's The House with the Green Shutters, Lewis Carroll's Alice in Wonderland, or Henrik Ibsen's Peer Gynt, to name just a few. Inevitably, the index also refers to a number of texts outside the three-fold typology of the arch-genres, and we find a number of heterogeneous entries under the names of the philosophers Thomas Hobbes, David Hume and Karl Marx; the influence of psychoanalysts Carl Jung and Sigmund Freud is also underlined; two newspapers such as the Imperial Gazetteer of Scotland and the Guardian are also mentioned; and even more disturbing is the reference to Walt Disney and his film Pinocchio, as well as to the figure of God in the verse drama Jonah. As we have seen above, the index is not to be followed to the letter, but, again, to dismiss the information provided here on the basis of its parodic aim would seem wrong. The practical outcome of such a vast amount of intertextual references is difficult to ascertain, but I believe that it certainly forces the reader to reflect on the nature of literature itself and, especially, on the active role assigned to the reader in poststructuralist linguistic theories.

Apart from the individualised analysis that each of these strategies may produce, there seems to be little doubt that the very accumulation of such a variety of typically postmodernist devices becomes somewhat suspicious. Readers may be tempted to interpret this as a big joke played at their expense, and therefore in line with Gray's statement that he does not belong to the postmodernist movement. Despite Gray's opposition I believe that a different analysis should be carried out: despite the humorous or even parodic atmosphere which seems to infuse this chapter, it should be taken as unambiguous evidence of the simultaneity between knowledge and experience, which may be considered as one of the fundamental features of postmodernism. Indeed, it is Steve Connor's contention that "we are in and of the moment that we are attempting to analyse, in and of the structures we employ to analyse it" (1991:5), which explains the self-reflexivity and self-consciousness which characterise the postmodernist moment. Similarly, Douwe Fokkema has stated that "the results of our analytical description of Postmodernism affect the practice of Postmodernism" (1986: 6), reminding us both of Robbe-Grillet's complaint that the critics' prompt analysis of his work had compelled him to look continuously for new devices, and of Norman Holland's remark that the awareness of living within the postmodernist period deprives the artist of a half-knowing innocence enjoyed at the beginning. Gray's novel seems to have been produced in a similar cultural/literary climate, and the Epilogue may be taken to epitomise this postmodernist anxiety: it may well be that in the Epilogue Gray unconsciously foreshadows a fear that he expressed years later, when he remarked that "since university teachers lecture on my books and students write dissertations on them, I have grown conscious of my academic audiences and afraid of seeming their property" (in Axelrod 1995: 113). Proving that the novel is the genre that most easily adapts itself to new 
circumstances, and that is most willing to push against its own limits, the experimental Epilogue engages its reader in a debate with contemporary literary theories: throughout the dialogue between Nastler and Lanark attention is drawn to the genesis of the novel, but then this very chapter is placed in context, and its presence is justified to some extent as a result of the contemporary literary panorama. This it does by incorporating a theoretical corpus with which to discuss the novel, thus simultaneously providing an adequate context -both theoretical and practical- in which to place and, perhaps, better read the novel.

\section{Notes}

1. This opposition between the order of books and that of chapters, which has already been anticipated by the peculiar Table of Contents at the very beginning of the novel, serves to underline the fictional author's statement that he wants the novel to be read in one order but eventually thought of in another (p. 483).

2. A brief but extremely useful analysis is that provided by Douglas Gifford in The Dear Green Place? The Novel in the West of Scotland: after setting out what he considers to be its main traits, he focuses on the twentieth-century development by establishing a clear distinction between the prewar period, the 1920s and 1930s in which the Scottish Renaissance is located, and the post-1945 period. Witschi's Glasgow Urban Writing and Postmodernism looks into the way in which Gray's Lanark is to be understood in relation to the Glasgow novel tradition, and therefore reflects upon the impact of postmodernist writing in an eminently realist literary tradition. Moira Burgess has probably made the greatest effort to acknowledge the presence of such a tradition: initially with the publication of her 1986 bibliography, and later with Imagine a City: Glasgow in Fiction in 1998. The latter, divided into four sections -Small City, Hard City, Kaleidoscope City and Deep Citycovers almost two centuries of writing concerned with Glasgow, dealing with well-known novels as well as bringing to light a number of rediscoveries.

3. Given Duncan Thaw's interest in, almost obsession with, art and becoming an artist, and his recurrent theorising about painting, the analysis of Books One and Two would certainly benefit from a discussion of it in terms of another subgenre, that of the Künstlerroman.

4. In Scottish Fantasy Literature. A Critical Survey (1994) and An Anthology of Scottish Fantasy Literature (1996) Manlove looks into the Scottish fantasy tradition by underlining its profusion and variety: traditional fairy tales, dream allegories, Spenserian romance, children's stories, travels to other worlds, ghost stories, comic tales, Christian mysteries and postmodernist visions (1996:8). He thus covers an initial fifteenth century phase -dream allegories such as Robert Henryson's The Testament of Cresseid, or those of William Dunbar and Gavin Douglas- which is followed by the Spenserian romance and Macpherson's Ossian in the eighteenth-century; next he refers to nineteenth-century Gothic fantasy and ghost story, represented by James Hogg (The Private Memoirs and Confessions of a Justified Sinner), Thomas Carlyle (Sartor Resartus), George MacDonald (Phantastes), or Robert Louis Stevenson (Dr Jekyll and Mr Hyde); and finally examines the twentieth century, which ranges from science fantasy and dystopian fiction to postmodernist and feminist fiction, with writers such as David Lindsay, Naomi Mitchison, Bruce Marshall, James Bridie, Neil Gunn, George Mackay Brown, Alasdair Gray, Liz Lochhead, Jain Banks, Sian Hayton, Margaret Elphistone and James Meek. It is Manlove's contention that Scottish fantasy is primarily concerned with the supernatural, which provides an alternative vision of reality -by means of an unusual angle or a grotesque inversion rather than an escape, and must therefore 
be understood to be linked with Hoffmann and Kafka rather than Lewis or Tolkien. Despite this European dimension, Manlove refers to a number of specific Scottish features, among which "the use of doubles and of dream structures is pervasive" (1996:11). These elements are essential for the analysis of Lanark.

5. Let us remember that Book Two closes in a climax of extreme ambiguity: within this atmosphere of uncertainty the reader is notprovided with enough information as to whether Duncan Thaw has killed Marjory and then committed suicide, or whether this is just the result of his distorted imagination. It is up to the reader to choose one or the other, or, rejecting the "law of excluded middles', accept both possibilities as potentially true, and carry out complementary readings.

6. This is a trip which would also benefit from archetypal or mythical readings. Not surprisingly, it is in the mocking Index that we read, under the entry "God", that "the purification by swallowing is a Difplag from the verse drama Jonah" (p. 488); it is also the Index which suggests two such intertexts as Herman Melville's Moby Dick (in footnote 12) and Milton's Paradise Lost (in footnote 6), as well as the names of Sigmund Freud and Carl Jung (together with Disney and God!).

\section{Works cited}

Axelrod, Mark (1995): "An Epistolary Interview, Mostly with Alasdair Gray". The Review of Contemporary Fiction XV, 2: 106-115.

Bell, Ian A. (1996): "Imagine Living There: Form and Ideology in Contemporary Scottish Fiction". In S. Hagemann, ed., Studies In Scottish Fiction: 1945 to the Present, 217-234.

Burgess, Moira (1986): The Glasgow Novel: A Survey and Bibliography. Glasgow: Scottish Library Association and Glasgow District Libraries.

(1998): Imagine a City: Glasgow in Fiction. Argyll: Argyll Publishing.

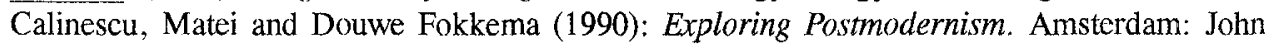
Benjamins.

Costa, Dominique (1994): "Decadence and Apocalypse in Gray's Glasgow-Lanark: A Postmodernist Novel". Scotia XVIII: 22-34.

Donaldson, George and Alison Lee (1995): "Is Eating People Really Wrong? Dining with Alasdair Gray". The Review of Contemporary Fiction XV(2): 155-161.

Figgis, Sean and Andrew McAllister (1988): "Alasdair Gray". Béte Noire 5 (Spring): 1744.

Fokkema, Douwe (1986): "The Semantic and Syntactic Organization of Postmodernist Texts". In

Douwe Fokkema and Hans Bertens, eds., Approaching Postmodernism.

Frye, Northrop (1965): "Variety of Literary Utopias". Daedalus, Spring: 323-347.

Genette, Gérard (1977): "Genres, 'types', modes". Poétique 32: 389-421.

Gifford, Douglas (1985): The Dear Green Place? The Novel in the West of Scotland. Glasgow:

Third Eye Centre.

Gray, Alasdair (1981): Lanark: A Life in 4 Books. London: Picador.

Hutcheon, Linda (1989): The Politics of Postmodernism. London: Routledge.

Kumar, Krishnar (1991): Utopianism. Buckingham: Open University Press.

Manlove, Colin (1994): Scottish Fantasy Literature. A Critical Survey. Edinburgh: Canongate Academic. . (ed)(1996): An Anthology of Scottish Fantasy Literature. Edinburgh: Polygon. 
McHale, Brian (1987): Postmodernist Fiction. London: Methuen.

Mihailescu, Calin Andrei (1991): "Mind the Gap: Dystopia as Fiction". Style 25(2): 211-222.

Nadeau, Robert (1981): Readings from the New Book on Nature. Amherst: The University of Massachusets Press.

Petro, Peter (1982): Modem Satire. Four Studies. New York: Mounton Publishers.

Roderick J. Lyall (1993): "Postmodernist otherworld, postcalvinist purgatory. An approach to Lanark and The Bridge". Etudes Écossaises 2: 41-52.

Spring, lan (1990): Phantom Village. The Myth of the New Glasgow. Edinburgh: Polygon.

Todorov, Tzvetan (1987): "L'origine des genres". In La notion de littérature et autres essais. Paris: Seuil.

Trousson, Raymond (1979): Voyages aux pays de nulle part. Histoire littéraire de la penseé utopique. Brussels: Editions de 1'Université de Bruxelles.

Witschi, Beat (1991): Glasgow Urban Writing and Postmodernism. A Study of Alasdair Gray's Fiction. Frankfurt am Mein: Peter Lang (Scottish Studies 12). 